Modeliranje pogodnosti poljoprivrednog zemljišta za uzgoj ječma uporabom višekriterijske GIS analize

Suitability modeling of agricultural land for barley cultivation using the multicriteria GIS analysis

Šiljeg, A., Jurišić, M., Radočaj, D., Videković, M.

Poljoprivreda/Agriculture

ISSN: $1848-8080$ (Online)

ISSN: 1330-7142 (Print)

http://dx.doi.org/10.18047/poljo.26.1.6

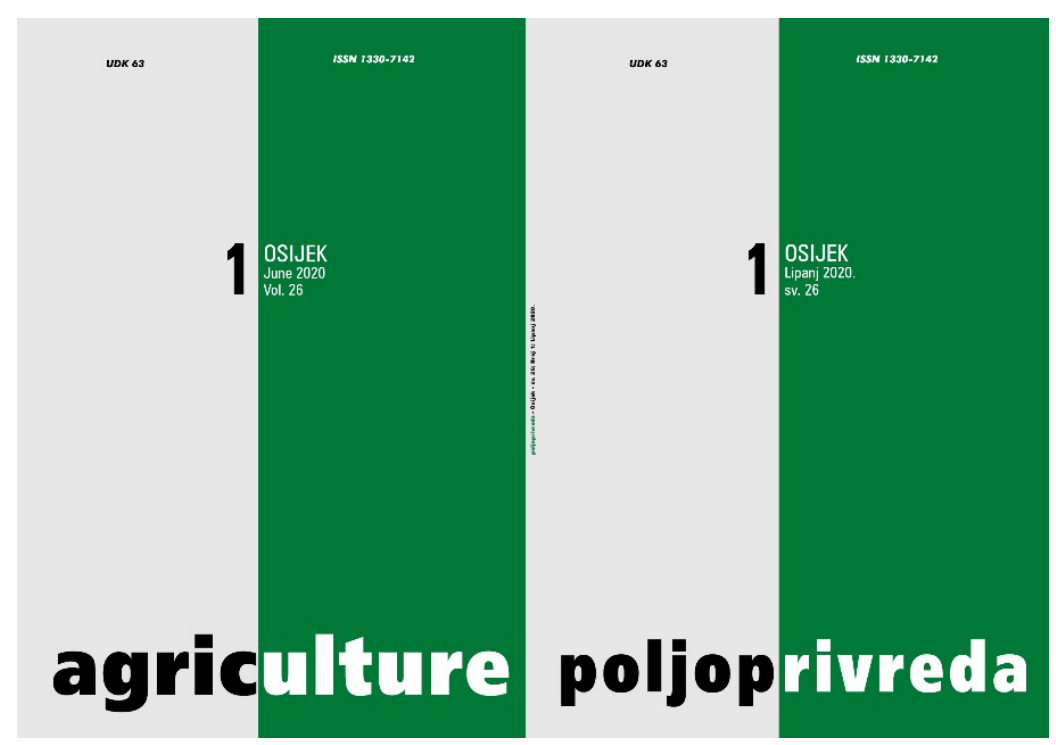

Fakultet agrobiotehničkih znanosti Osijek, Poljoprivredni institut Osijek

Faculty of Agrobiotechnical Sciences Osijek, Agricultural Institute Osijek 


\title{
MODELIRANJE POGODNOSTI POLJOPRIVREDNOG ZEMLJIŠTA ZA UZGOJ JEČMA UPORABOM VIŠEKRITERIJSKE GIS ANALIZE
}

Šiljeg, A. ${ }^{(1)}$, Jurišić, M. ${ }^{(2)}$, Radočaj, D. ${ }^{(2)}$,Videković, M. ${ }^{(1)}$

Izvorni znanstveni članak

Original scientific paper

\begin{abstract}
SAŽETAK
Važnost primjene višekriterijske analize primjenom Geografskoga informacijskog sustava (GIS-a) u planiranju poljoprivredne proizvodnje u porastu je zbog sve veće potrebe za boljim i održivim iskorištavanjem zemljišnih resursa. $U$ ovome je istraživanju izrađen model izračuna pogodnosti poljoprivrednoga zemljišta Osječkobaranjske županije za uzgoj ječma primjenom višekriterijske GIS analize. Postupak istraživanja proveden je u skladu s temeljnim koracima višekriterijske GIS analize: postavljanjem cilja analize, određivanjem kriterija, standardizacijom vrijednosti, određivanjem težina kriterija, objedinjavanjem standardiziranih vrijednosti i težina kriterija te validacijom rezultata. Pri izračunu pogodnosti korišteno je pet skupina kriterija: geomorfometrijski, klimatski, pedološki, hidrološki i ograničavajući kriteriji. Težinski koeficijenti kriterija određeni su metodom analitičkoga hijerarhijskog procesa (AHP). Vrijednosti pogodnosti reklasificirane su prema standardu pogodnosti poljoprivrednoga zemljišta Organizacije za prehranu i poljoprivredu (FAO) u pet klasa. Rezultati istraživanja pokazali su da je prostor Osječko-baranjske županije dominantno umjereno pogodan (S2) za uzgoj ječma s $53,00 \%$ poljoprivrednoga zemljišta. Najviša točnost izračunane površine u odnosu na površine testnih ARKOD čestica postignuta je za vrlo pogodnu (S1) kategoriju pogodnosti u iznosu 99,82\%. Izrađeni model predstavlja temelj za izračun pogodnosti ostalih kultura na području Osječko-baranjske županije, na mezo- i mikrorazini istraživanja.
\end{abstract}

Ključne riječi: model pogodnosti, ječam, FAO klase pogodnosti, GIS, Osječkobaranjska županija

\section{UVOD}

Globalne projekcije do 2050. godine ukazuju na rastuću potrebu proizvodnje hrane, čime se nameće potreba za povećanjem kvalitete i količine proizvedenih poljoprivrednih proizvoda (Bodirsky i sur., 2015.). Geografski informacijski sustav (GIS) posljednjih se godina nametnuo kao optimalno rješenje kod modeliranja utjecaja raznih prostorno vezanih komponenata glede pogodnosti zemljišta za ratarsku proizvodnju. Uporabom višekriterijskih GIS analiza utjecaj definiranih kriterija objedinjuje se u jedinstveni rezultat pogodnosti s jasno definiranim zonama pogodnosti za uzgoj pojedinih poljoprivrednih kultura. Višekriterijske GIS analize pogodnosti omogućuju rješavanje kompleksnih problema s ciljem ostvarenja veće kvalitete i količine prinosa poljoprivrednih kultura (Zhang i sur., 2015.). Primjena rezultata višekriterijskih GIS analiza u poljoprivredi očituje se kroz smanjenje upotrebe gnojiva i herbicida, smanjenje onečišćenja okoliša, povećanje prinosa te veću kontrolu uzgoja (Davis i sur., 2017.). Klimatološki, pedološki i geomorfometrijski kriteriji neki su od najčešće korištenih skupina kriterija za modeliranje pogodnosti poljoprivrednoga zemljišta za uzgoj poljoprivrednih kultura (Kazemi i Akinci, 2018.; Yohannes i Soromessa, 2018.). Vrijednosti svih definiranih kriterija standardiziraju se u jedinstveni brojčani interval prema razini pogodnosti na području istraživanja (Plaščak i sur., 2019.). Nezaobilazan korak

(1) Izv. prof. dr. sc. Ante Šiljeg, Matej Videković, mag. geogr. Sveučilište u Zadru, Odjel za geografiju, Ulica Franje Tuđmana 24 i, 23000 Zadar, Hrvatska; (2) Prof. dr. sc. Mladen Jurišić (mjurisic@fazos. hr), Dorijan Radočaj, mag. ing. geod. et geoinf. - Sveučilište Josipa Jurja Strossmayera u Osijeku, Fakultet agrobiotehničkih znanosti, Vladimira Preloga 1, 31000 Osijek, Hrvatska 
kod modeliranja pogodnosti jest računanje težina kriterija, kao mjera razine utjecaja pojedinih kriterija na konačan rezultat (Jurišić i sur., 2020.). Metoda analitičkoga hijerarhijskog procesa (AHP) jedna je od najčešće korištenih metoda određivanja težina kriterija, a svoju prepoznatljivost stekla je zbog fleksibilnosti i temeljitosti računanja (Musakwa, 2018.). Objedinjene standardizirane vrijednosti i težine kriterija najčešće se klasificiraju prema preporukama Organizacije za prehranu i poljoprivredu (FAO) u pet klasa, što rezultira usklađenošću rezultata pogodnosti na globalnoj razini (Kazemi i Akinci, 2018.). Validacija rezultata pogodnosti provodi se temeljem usporedbe sa stvarnim stanjem pogodnosti na terenu, najčešće putem vegetacijskih indeksa (Radočaj i sur., 2020.) ili količinom prinosa poljoprivrednih kultura (Dedeoğlu i Dengiz, 2019.).

Ječam je jedna od najstarijih ratarskih kultura, čiji se početci uzgoja mogu pratiti i sve do antičkoga Egipta (Hornsey, 2003.). Zbog svoje hranjive vrijednosti, otpornosti na vanjske utjecaje te dobre prilagodljivosti, prepoznat je ne samo u proizvodnji stočne hrane, već i u farmaceutskoj, tekstilnoj i pivarskoj industriji (Martinčić i Kolak, 1993.). Uzgoj ječma, posebice pivarskoga, postaje sve prepoznatljiviji u Republici Hrvatskoj te dolazi do povećanja površina zasijanih ječmom. Posljedično se nametnula i potreba za izradbom i opisivanjem mode- la pogodnosti koji će pridonijeti boljem razumijevanju trenutačne stvarnosti, upravljanja zemljištem i u konačnici boljem uzgoju ječma.

Cilj ovoga istraživanja jest izradba modela vrjednovanja poljoprivrednoga zemljišta za uzgoj ječma na području Osječko-baranjske županije korištenjem višekriterijske GIS analize. Hipoteza rada jest ta da je primjenom višekriterijske GIS analize moguće klasificirati pogodnost poljoprivrednoga zemljišta za uzgoj ječma s visokom točnošću, što je ispitano u odnosu na testne poljoprivredne čestice. Izračunane vrijednosti pogodnosti poljoprivrednoga zemljišta za uzgoj ječma kartirane su kao potpora odlučivanju pri upravljanju poljoprivrednim zemljištem na razini Županije.

\section{MATERIJAL I METODE}

Područje je istraživanja Osječko-baranjska županija (SI. 1), smještena na istoku Hrvatske, ukupne površine $4.155 \mathrm{~km}^{2}$. Osječko-baranjska županija smještena je na dodiru Drave i Dunava, prostoru Vučičko-karašičke Podravine, Baranje, Donjodravsko-dunavske ravnice i krndijskoga osojnog pobrđa. Umjerena kontinentalna klima i plodno tlo glavni su čimbenici poljoprivredne djelatnosti na području istraživanja (Magaš, 2013.).

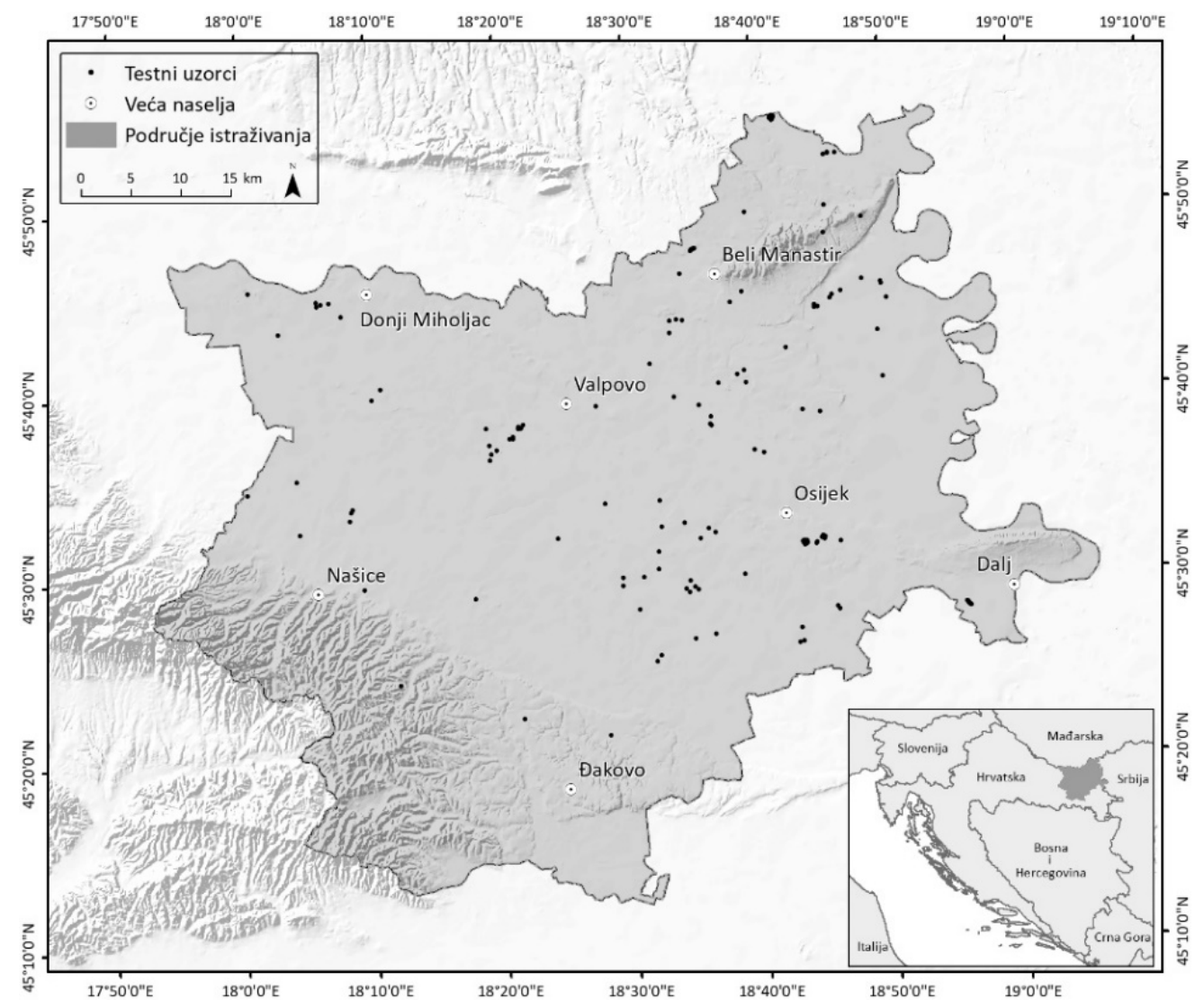

Slika 1. Područje istraživanja

Figure 1. Study area 
Postupak višekriterijske GIS analize proveden je u skladu sa šest temeljnih koraka (Domazetović i sur., 2019.): postavljanje cilja višekriterijske GIS analize, određivanje kriterija, standardizacija vrijednosti kriterija, određivanje težina kriterija, objedinjavanje standardiziranih vrijednosti i težina kriterija te validacija rezultata. Rezultat pogodnosti poljoprivrednoga zemljišta za uzgoj ječma na području Osječko-baranjske županije izrađen je u računalnome GIS programu ArcMap 10.1.

Model pogodnosti izrađen je primjenom višekriterijske GIS analize na temelju pet kriterijskih skupina, odabranih temeljem analize prethodnih istraživanja prikazanih u Tablici 1. Nadmorska visina i nagib terena odabrani su jer uvjetuju dubinu zemljišta, stupanj erozije i zadržavanje vode. Nagib terena generiran je iz DMR-a metodom $3 \times 3$ kvadrata, gdje se izračunava maksimalna promjena vrijednosti visina između središnje ćelije $\mathrm{i}$ osam okružujućih ćelija (Šiljeg i sur., 2018.). Ekspozicija predstavlja stranu svijeta na koju je okrenuta određena ploha, a kako je svim biljkama potrebno sunce za rast i razvoj, južna, jugoistočna i jugozapadna ekspozicija su favorizirane jer predstavljaju prisojnu stranu padina.

Pedološka skupina kriterija obuhvaća fizička i kemijska svojstva tla, u što su ubrojeni kiselost, tip i tekstura tla. Kiselost ili lužnatost tla izražena je pH vrijednošću. Optimalne vrijednosti pH tla za uzgoj ječma klasificirane su od 6,2 do 7,5 . Najveću površinu tala na području istraživanja zauzimaju djelomično hidromeliorirana močvarno glejna tla, tla lesivirana na praporu i aluvijalna tla. Kao najpogodniji tipovi tla odabrana su aluvijal- na, aluvijalno-livadna, černozem na praporu i eutrično smeđa tla. Najpogodnija tekstura za ječam su ilovasta i pjeskovito ilovasta tla zbog dobre ocjeditosti tla.

Prema podatcima WorldClim 2 za područje Osječko-baranjske županije (1970.-2000.), prosječna godišnja temperatura zraka kreće se od 8,2 do $11,2^{\circ} \mathrm{C}$ (Fick i Hijmans, 2017), dok su optimalne temperature za razvoj ječma od 10 do $12^{\circ} \mathrm{C}$. Oborine su zonalno raspoređene na području istraživanja od jugozapada prema sjeveroistoku. Minimalne vrijednosti iznose $619 \mathrm{~mm}$ na godinu, dok maksimalne vrijednosti iznose $858 \mathrm{~mm}$ na godinu, zbog čega je područje istraživanja većim dijelom u drugoj, a manjim dijelom u prvoj kategoriji pogodnosti.

Hidrološki kriteriji usko su vezani uz kriterij nagiba i teksture tla. Klase ocjeditosti terena su sljedeće: dobra, umjereno dobra, nepotpuna, slaba i vrlo slaba ocjeditost. Područja s dobrom i umjereno dobrom ocjeditošću nalaze se na reljefno izraženijim i nagnutijim terenima, a područja s nepotpunom i slabom ocjeditošću u zaravnjenim dijelovima i uz vodotoke. Erozija zemljišta dobivena je na temelju izrađenoga modela pogodnosti materijala erodiranju s obzirom na 10 topografskih indeksa.

Ograničavajući kriteriji predstavljaju područja na kojima se nije moguće koristiti zemljištem u svrhu poljoprivredne proizvodnje. Modeliranje ograničavajućih kriterija provedeno je temeljem Booleanskog principa. Vrijednosti 0 označavaju sve one površine na kojima ne može doći do uzgoja ječma, a vrijednosti 1 predstavljaju površine na kojima je moguć uzgoj.

Tablica 1. Kriteriji za modeliranje pogodnosti za uzgoj ječma

Table 1. Criteria for the modeling of barley cultivation suitability

\begin{tabular}{|c|c|c|c|c|}
\hline & $\begin{array}{l}\text { Kriteriji } \\
\text { Criteria }\end{array}$ & $\begin{array}{l}\text { Izvor podataka } \\
\text { Data source }\end{array}$ & $\begin{array}{c}\text { Jedinica } \\
\text { Unit }\end{array}$ & $\begin{array}{l}\text { Referenca } \\
\text { Reference }\end{array}$ \\
\hline \multirow{3}{*}{ 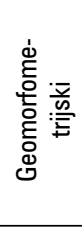 } & $\begin{array}{l}\text { Nadmorska } \\
\text { visina }\end{array}$ & \multirow{3}{*}{ SRTM (USGS, 2015.) } & $\mathrm{m}$ & Akinci i sur. (2013.), Zhang i sur. (2015.), Yohannes i Soromessa (2018.) \\
\hline & Nagib & & $\%$ & $\begin{array}{l}\text { Akinci i sur. (2013.), Zhang i sur. (2015.), Yohannes i Soromessa (2018.), Ennaji } \\
\text { i sur. (2018.) }\end{array}$ \\
\hline & Ekspozicija & & $\begin{array}{l}\text { strana } \\
\text { svijeta }\end{array}$ & Akinci i sur. (2013.), Yohannes i Soromessa (2018.) \\
\hline \multirow{3}{*}{$\begin{array}{l}\frac{7}{30} \\
\frac{0}{0} \\
\frac{0}{0}\end{array}$} & Kiselost tla & \multirow{3}{*}{$\begin{array}{c}\text { PK } 300 \\
\text { (Bogunović i sur., } \\
\text { 1997.) }\end{array}$} & $\mathrm{pH}$ & $\begin{array}{l}\text { Kazemi i Akinci (2018.), Zhang i sur. (2015.), Yohannes i Soromessa (2018.), } \\
\text { Ennaji i sur. (2018.) }\end{array}$ \\
\hline & Tip tla & & klasa & Akinci i sur. (2013.), Zhang i sur. (2015.) \\
\hline & Tekstura tla & & klasa & Kazemi i Akinci (2018.), Yohannes i Soromessa (2018.), Ennaji i sur. (2018.) \\
\hline \multirow{2}{*}{ 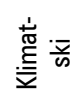 } & Temperatura & \multirow{2}{*}{$\begin{array}{c}\text { WorldClim } 2 \\
\text { (Fick i Hijmans, 2017.) }\end{array}$} & ${ }^{\circ} \mathrm{C}$ & Kazemi i Akinci (2018.), Zhang i sur. (2015.), Yohannes i Soromessa (2018.) \\
\hline & Oborine & & $\mathrm{mm}$ & Kazemi i Akinci (2018.), Zhang i sur. (2015.), Yohannes i Soromessa (2018.) \\
\hline \multirow{2}{*}{ 홓 흥 } & Ocjeditost & \multirow{2}{*}{$\begin{array}{c}\text { SRTM } \\
\text { (USGS, 2015.) }\end{array}$} & klasa & Yohannes i Soromessa (2018.), Sarkar i sur. (2014.) \\
\hline & Erozija & & klasa & Akinci i sur. (2013.), Kazemi i Akinci (2018.), Yohannes i Soromessa (2018.) \\
\hline \multirow{6}{*}{ 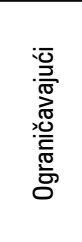 } & Prometnice & \multirow{6}{*}{$\begin{array}{c}\text { OSM (OSM } \\
\text { Contributors, 2019.) }\end{array}$} & - & Yohannes i Soromessa (2018.), Sarkar i sur. (2014.) \\
\hline & Izgrađeno & & - & Yohannes i Soromessa (2018.), Sarkar i sur. (2014.) \\
\hline & Travnjaci & & - & Yohannes i Soromessa (2018.), Sarkar i sur. (2014.), Akinci i sur. (2013.) \\
\hline & Trajni nasadi & & - & Sarkar i sur. (2014.) \\
\hline & Vode & & - & Sarkar i sur. (2014.) \\
\hline & Šume & & - & Yohannes i Soromessa (2018.), Sarkar i sur. (2014.), Akinci i sur. (2013.) \\
\hline
\end{tabular}

SRTM: Shuttle Radar Topography Mission, PK 300: Pedološka karta u mjerilu 1:300.000, OSM: OpenStreetMap 
Standardizacija vrijednosti kriterija provedena je metodom klasiranja unutar brojčanoga intervala od 1 do 5, pri čemu su za svaku klasu određeni rasponi vrijednosti. Svi kriteriji određeni su u 5-metarskoj prostornoj rezoluciji (udaljenost na površini Zemlje koju predstavlja pojedini piksel) u projekcijskome koordinatnom sustavu HTRS96/TM.

Težinski koeficijenti određeni su metodom analitičkoga hijerarhijskog procesa (AHP) kao jednom od najpoznatijih i najkorištenijih metoda u rješavanju problema kada postoji više raspoloživih mogućnosti (Crnčan i sur., 2016.). AHP-om je kompleksna višekriterijska GIS analiza podijeljena na manje komponente i uređena u hijerarhiju. Te komponente predstavljaju zadane kriterije koji su uspoređeni u odnosu na druge pomoću matrice usporedbe parova kriterija, a rezultat je te usporedbe skup prioriteta kriterija (Saaty, 2008.). Za usporedbu kriterija odabran je interval brojeva $1-9$, koji pokazuje koliko je puta važniji ili dominantniji jedan element nad drugim elementom. Postupak izračuna težina unutar AHP metode detaljno je opisao Saaty (2008.). Konzistencija matrice usporedbe parova provjerena je prema formulama (1) i (2) (Saaty, 1990.):

$$
\begin{gathered}
C R=\frac{C I}{R I}, \\
C I=\frac{\lambda_{\text {max }}-n}{n-1},
\end{gathered}
$$

pri čemu je $C R$ omjer konzistencije, $C l$ indeks konzistentnosti, $R I$ indeks slučajne konzistencije, $\lambda_{\max }$ svojstvena vrijednost, a $n$ broj kriterija. Indeks slučajne konzistencije ovisi o broju kriterija u izrađenoj matrici, te je za svaki broj kriterija različit. Ako je vrijednost omjera konzistencije manja ili jednaka 0,1 , nedosljednost je prihvatljiva, a ako je veća od 0,1 , tada se treba provesti revizija subjektivne prosudbe donositelja odluka (Saaty, 1990.).

Objedinjavanje kriterija za određivanje najpogodnijega područja i najboljih alternativa provedeno je množenjem standardiziranih vrijednosti i odgovarajućih težina te izdvajanjem ograničenih područja. Izračun zemljišnoga indeksa koji ukazuje na razinu pogodnosti poljoprivrednoga zemljišta za uzgoj ječma izračunan je metodom težinske linearne kombinacije (3) (Eastman, 1999.):

$$
\text { zemljišni indeks }=\sum w_{i} X_{i} \cdot 20 \cdot \Pi C,
$$

pri čemu je $w_{i}$ težinski koeficijent kriterija, $X_{i}$ standardizirana vrijednost kriterija, a ПC umnožak ograničenja. Izrađeni model pogodnosti preklopljen je s ograničavajućim kriterijima, pri čemu je iz rezultata izdvojeno samo poljoprivredno zemljište koje ne sadrži niti jedno ograničenje. Klasifikacija pogodnosti provedena je u pogodne (S) i nepogodne klase (N), koje se dalje dijele na podklase prema vrijednostima zemljišnoga indeksa u skladu sa specifikacijama u (FA0, 1976.). Vrijednosti objedinjenih standardiziranih vrijednosti i njihovih težina pomnožene su s 20, čime je ostvarena poveznica između FAO klasa pogodnosti i intervala zemljišnoga indeksa koje su definirali Akinci i sur. (2013.) (Tablica 2). Klasa S1 (vrlo pogodno) predstavlja zemljišta koja nemaju značajna ograničenja za trajnu uporabu ili imaju samo manja ograničenja koja ne će u većoj mjeri smanjiti produktivnost. Klasa S2 (umjereno pogodno) predstavlja zemljišta čija su ograničenja umjerena za trajnu uporabu te ograničenja koja će smanjiti produktivnost i povećati potrebe inputa u tolikoj mjeri da će biti dovoljno atraktivna, ali inferiornija u odnosu na klasu S1. Klasa S3 (marginalno pogodno) predstavlja zemljišta s ograničenjima koja su u cjelini ozbiljna za trajnu uporabu i time smanjuju produktivnost i povećavaju inpute za uporabu. Klasa N1 (trenutačno nepogodno) predstavlja zemljište koje ima ograničenja koja mogu biti vremenski premostiva, ali koja se trenutačnom tehnologijom i neprihvatljivim cijenama ne mogu otkloniti. Klasa N2 (trajno nepogodna) predstavlja zemljište s ograničenjem u tolikoj mjeri da onemogućavaju bilo kakvu mogućnost korištenja zemljišta na održivi način, a to su najčešće fizička i trajna ograničenja.

Tablica 2. Vrijednosti zemljišnoga indeksa prema FAO-vim klasama pogodnosti

Table 2. Land index values according to the FAO suitability classes

\begin{tabular}{|c|c|c|}
\hline $\begin{array}{c}\text { FA0 klasa pogodnosti } \\
\text { FAO suitability class }\end{array}$ & $\begin{array}{c}\text { Naziv klase } \\
\text { Class name }\end{array}$ & $\begin{array}{c}\text { Zemljišni indeks } \\
\text { Land index }\end{array}$ \\
\hline S1 & Vrlo pogodna & $100-80$ \\
\hline S2 & Umjereno pogodna & $80-60$ \\
\hline S3 & Marginalno pogodna & $60-40$ \\
\hline N1 & Trenutno nepogodna & $40-20$ \\
\hline N2 & Trajno nepogodna & $20-0$ \\
\hline
\end{tabular}


Validacija modela pogodnosti poljoprivrednoga zemljišta za uzgoj ječma provedena je u odnosu na ARKOD čestice na kojima je identificiran ječam kao poljoprivredna kultura u 2019. godini. Testne ARKOD čestice obuhvaćaju površinu od 4999 ha i ravnomjerno su raspoređene na području istraživanja. Točnost modela procijenjena je usporedbom udjela površina FAO-vih klasa pogodnosti izračunanoga modela i testnih ARKOD čestica, kojima je dodijeljen atribut istih klasa pogodnosti prijeklopom s izračunanim modelom.

\section{REZULTATI I RASPRAVA}

Vrijednosti kriterija nadmorske visine kreću se od 80 do 625 metara, te je cijeli prostor 0sječko-baranjske županije svrstan u klasu S1 (Tablica 3). Vrijednosti kriterija nagiba kreću se od 0 do $31,71 \%$, pa je stoga standardiziran u svih pet klasa. Veći nagibi prisutni su u brdskim i gorskim prostorima, na sjeveroistočnoj $\mathrm{i}$ jugo- zapadnoj strani Županije. Ekspozicija je standardizirana u četirima klasama, koje predstavljaju glavne strane svijeta (jug, istok, zapad i sjever). Vrijednosti kriterija kiselosti tla kreću se od 4,0 do 8,23, a standardizirane su u četiri klase. Vrijednosti teksture tla standardizirane su u tri klase, od kojih je najpogodnija klasa s glinasto ilovastom, ilovastom i praškasto ilovastom teksturom. Vrijednosti srednje godišnje temperature kreću se od 8,2 do $11,2^{\circ} \mathrm{C}$. Većina površine 0 sječko-baranjske županije spada u prvu klasu, dok su vrijednosti druge klase zastupljene samo na većim nadmorskim visinama na jugozapadu Županije. Prosječne godišnje količine oborina su također standardizirane u dvije klase. Vrijednosti erozijskog potencijala kreću se od 0 do 5 , gdje su vrijednostima od 0 do 1 izraženi prostori na kojima nije moguća erozija (vodene površine i izgrađeno). Na geomorfološki izraženijem području veći su nagibi terena uzrokovali veći erozijski potencijal, što je prikazano u sličnome istraživanju (Domazetović i sur., 2019.).

Tablica 3. Raspon pogodnosti standardiziranih kriterija

Table 3. Suitability ranges of the standardized criteria

\begin{tabular}{|c|c|c|c|c|c|}
\hline \multirow{2}{*}{$\begin{array}{l}\text { Naziv kriterija } \\
\text { Criteria name }\end{array}$} & \multicolumn{5}{|c|}{$\begin{array}{l}\text { Raspon pogodnosti } \\
\text { Suitability range }\end{array}$} \\
\hline & S1 & S2 & S3 & N1 & N2 \\
\hline $\begin{array}{l}\text { Nadmorska } \\
\text { visina }(\mathrm{m})\end{array}$ & $0-1500$ & $1500-2300$ & $2300-3300$ & $3300-3800$ & $>4500$ \\
\hline Nagib (\%) & $0-8$ & $8-16$ & $16-24$ & $24-30$ & $>30$ \\
\hline Ekspozicija & Jug & Istok & Zapad & Sjever & - \\
\hline Kiselost tla & $6,2-7,5$ & $\begin{array}{l}5,8-6,2 \\
7,5-8,0\end{array}$ & $\begin{array}{l}5,5-5,8 \\
8,0-8,5\end{array}$ & - & $\begin{array}{l}<5,5 \\
>8,5\end{array}$ \\
\hline Tip tla & $\begin{array}{l}\text { Černozem, Aluvijalno, } \\
\text { Eutrično smeđe }\end{array}$ & $\begin{array}{l}\text { Arenosol antropogenizirani, } \\
\text { Lesivirano, Rigolano }\end{array}$ & $\begin{array}{c}\text { Eutrično smeđe, } \\
\text { Distrično smeđe, } \\
\text { Koluvij, Rendizina, } \\
\text { Rigolano krša, Sirozem }\end{array}$ & Gitja & $\begin{array}{l}\text { Crnica vap. dolomitna, } \\
\text { Kamenjar, } \\
\text { Podzol, Ranker humusno } \\
\text { silikatni }\end{array}$ \\
\hline Tekstura tla & $\begin{array}{c}\text { Glinasto ilovasta, } \\
\text { ilovasta, } \\
\text { praškasto } \\
\text { ilovasta }\end{array}$ & $\begin{array}{l}\text { Pjeskovito } \\
\text { glinasta, } \\
\text { pjeskovito } \\
\text { ilovasta }\end{array}$ & $\begin{array}{c}\text { Pjeskovito } \\
\text { ilovasta, ilovasto } \\
\text { pjeskovita }\end{array}$ & - & $\begin{array}{l}\text { Praškasto } \\
\text { glinasta, } \\
\text { glinasta }\end{array}$ \\
\hline Temperatura $\left({ }^{\circ} \mathrm{C}\right)$ & $10-12$ & $\begin{array}{c}6-8 \\
12-18\end{array}$ & $\begin{array}{c}4-6 \\
18-24\end{array}$ & $\begin{array}{c}2-4 \\
24-28\end{array}$ & $\begin{array}{l}<2 \\
>28\end{array}$ \\
\hline Oborine $(\mathrm{mm})$ & $400-650$ & $\begin{array}{l}300-400 \\
650-900\end{array}$ & $\begin{array}{l}200-300 \\
900-1300\end{array}$ & $\begin{array}{c}150-200 \\
1300-1500\end{array}$ & $\begin{array}{l}<150 \\
>1500\end{array}$ \\
\hline Ocjeditost & Dobra & Umjereno dobra & $\begin{array}{l}\text { Nepotpuna - } \\
\quad \text { slaba }\end{array}$ & Slaba & Vrlo slaba \\
\hline Erozija & Vrlo nisko & Nisko & Umjereno & Visoko & Vrlo visoko \\
\hline
\end{tabular}

Tablica 4 sadrži vrijednosti pridodane svakom kriteriju u matrici, a donesene su na temelju proučavane literature. Tip tla određen je kao kriterij s najvećim utjecajem na pogodnost, nakon čega slijede tekstura i pH tla. Konzistencija matrice rezultirala je unutar dopuštenih odstupanja. Pedološki kriteriji poput $\mathrm{pH}$, dubine tla, tipa tla ili teksture tla imaju najveće težinske koeficijente u sličnim istraživanjima (Akinci i sur., 2013.; Ennaji i sur., 2018.). 
Tablica 4. Matrica usporedbe parova u AHP metodi

Table 4. Pairwise comparison matrix in the AHP method

\begin{tabular}{|l|c|c|c|c|c|c|c|c|c|c|c|}
\hline & \multicolumn{9}{|c|}{$\begin{array}{c}\text { Kriterij } \\
\text { Criterion }\end{array}$} & $\begin{array}{c}\text { Težinski koeficijent } \\
\text { Weight coefficient }\end{array}$ \\
\cline { 2 - 16 } & Tip & Teks. & pH & Nag. & Pada. & Dren. & Eroz. & Eksp. & Temp. & Nad. v. \\
\hline Tip & 1 & 2 & 3 & 4 & 5 & 5 & 5 & 6 & 7 & 9 & 0,288 \\
\hline Teks. & $1 / 2$ & 1 & 2 & 2 & 2 & 3 & 3 & 4 & 5 & 6 & 0,163 \\
\hline pH & $1 / 3$ & $1 / 2$ & 1 & 2 & 3 & 3 & 3 & 4 & 5 & 6 & 0,144 \\
\hline Nag. & $1 / 4$ & $1 / 2$ & $1 / 2$ & 1 & 2 & 2 & 2 & 3 & 4 & 5 & 0,100 \\
\hline Pada. & $1 / 5$ & $1 / 2$ & $1 / 3$ & $1 / 2$ & 1 & 2 & 3 & 3 & 4 & 5 & 0,090 \\
\hline Dren. & $1 / 5$ & $1 / 3$ & $1 / 3$ & $1 / 2$ & $1 / 2$ & 1 & 3 & 3 & 4 & 5 & 0,078 \\
\hline Eroz. & $1 / 5$ & $1 / 3$ & $1 / 3$ & $1 / 2$ & $1 / 3$ & $1 / 3$ & 1 & 2 & 3 & 3 & 0,052 \\
\hline Eksp. & $1 / 6$ & $1 / 4$ & $1 / 4$ & $1 / 3$ & $1 / 3$ & $1 / 3$ & $1 / 2$ & 1 & 2 & 3 & 0,038 \\
\hline Temp. & $1 / 7$ & $1 / 5$ & $1 / 5$ & $1 / 4$ & $1 / 4$ & $1 / 4$ & $1 / 3$ & $1 / 2$ & 1 & 3 & 0,029 \\
\hline Nad. v. & $1 / 9$ & $1 / 6$ & $1 / 6$ & $1 / 5$ & $1 / 5$ & $1 / 5$ & $1 / 3$ & $1 / 3$ & $1 / 3$ & 1 & 0,019 \\
\hline
\end{tabular}

$C l=0,086 ; R l=1,490 ; C R=0,058$

Okupljenim kriterijima dodane su vrijednosti ograničavajućih faktora, te je izlazni rezultat model pogodnosti (SI. 2). Ukupno $44,18 \%$ područja istraživanja ograničeno je jednim ili s više ograničavajućih kriterija. Najveća područja klase S1 nalaze š uz rijeku Vuku, prateći njezin tok, na istočnome dijelu Županije južno od rijeke Drave (Bijelo Brdo, Dalj, Aljmaš, Erdut), središnjem (Bilje i Ceminac) i sjevernom dijelu Baranje (sjeverno i južno od Banskog brda) uz granicu s Mađarskom (Beli Manastir, Kneževo, Petlovac). Razlog tomu je taj što se na tim područjima nalaze tla visoke kvalitete, koja po svojim teksturama i kiselosti pripadaju klasama pogodnosti S1: aluvijalna tla, semiglejni i tipični černozem na praporu te eutrično smeđe tlo. Udjeli klasa pogodnosti za uzgoj ječma na području istraživanja prikazani su u Tablici 5 . Ukupno $51,98 \%$ područja procijenjeno je kao pogodno za uzgoj ječma, prilikom čega dominira klasa umjerene pogodnosti.

Validacijom izračunanoga modela pogodnosti zemljišta za uzgoj ječma utvrđeno je kako je najviša točnost postignuta za klase pogodnosti S1 i N1. Najviša relativna točnost postignuta je za klasu pogodnosti S1, s $99,82 \%$ poklapanja između površina modeliranoga i testnoga poljoprivrednog zemljišta. Najviše odstupanje izračunanoga modela pogodnosti u odnosu na testne parcele zabilježeno je za klasu pogodnosti S3, pri čemu se poklapa $72,08 \%$ identificiranoga poljoprivrednog zemljišta. Najpogodnija klasa pogodnosti S1 za uzgoj ječma izračunana je na površini od $64.703,76$ ha, odnosno na $15,62 \%$ površine 0sječko-baranjske županije ili na $27,98 \%$ neograničenoga poljoprivrednog zemljišta.

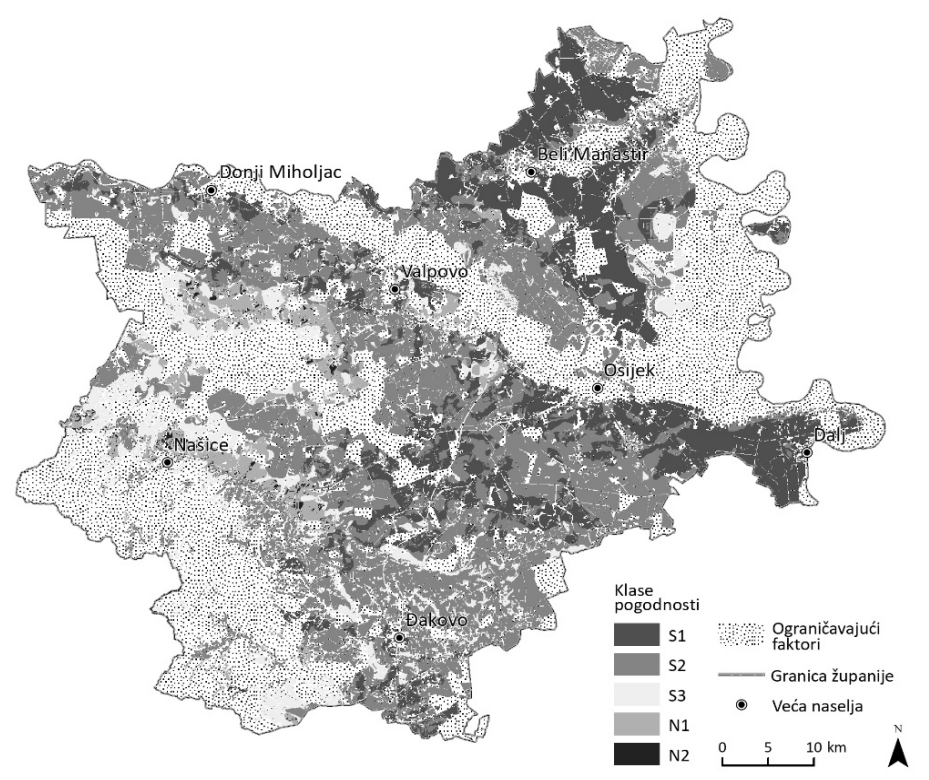

Slika 2. Model pogodnosti poljoprivrednoga zemljišta za uzgoj ječma u Osječko-baranjskoj županiji

Figure 2. Suitability model for barley cultivation in Osijek-Baranja County 
Tablica 5. Validacija modela pogodnosti u odnosu na ARKOD testne parcele

Table 5. Validation of suitability classes according to the ARKOD test parcels

\begin{tabular}{|c|c|c|c|}
\hline $\begin{array}{c}\text { Klase pogodnosti } \\
\text { Suitability classes }\end{array}$ & $\begin{array}{c}\text { Udio ukupne površine (\%) } \\
\text { Total area content (\%) }\end{array}$ & $\begin{array}{c}\text { Udio površine testnih parcela (\%) } \\
\text { Test parcels area content (\%) }\end{array}$ & $\begin{array}{c}\text { Razlika (\%) } \\
\text { Difference (\%) }\end{array}$ \\
\hline S1 & 27,98 & 27,93 & $-0,05$ \\
\hline S2 & 53,00 & 56,89 & 3,89 \\
\hline S3 & 12,14 & 8,75 & $-3,39$ \\
\hline N1 & 6,27 & 6,36 & 0,09 \\
\hline N2 & 0,61 & 0,08 & $-0,53$ \\
\hline
\end{tabular}

\section{ZAKLJUČAK}

Pri određivanju kriterija, najveći težinski koeficijenti su pridodani pedološkim kriterijima zbog toga što ječam ne podnosi tla slabije kvalitete, kisela ili slabo ocjedita tla. Kriteriji temperature, oborina i nadmorske visine nisu imali značajniju ulogu s obzirom na rezultat pogodnosti jer su gotovo cijelom svojom površinom predstavljeni jednom klasom. Autori preporučuju modeliranje tih kriterija interpolacijom vrijednosti prikupljenih meteorološkim stanicama u budućim istraživanjima. Ukupno $51,98 \%$ područja istraživanja procijenjeno je u nekoj mjeri kao pogodno za uzgoj ječma, dok je $44,18 \%$ ograničeno za poljoprivrednu proizvodnju. Validacijom je utvrđeno kako je postignuta konstantno visoka točnost izračuna pogodnosti poljoprivrednoga zemljišta za uzgoj ječma, u intervalu od 72,08 do $99,82 \%$. Najviša točnost postignuta je za klasu pogodnosti $S 1$, što ukazuje na mogućnost pouzdanoga određivanja područja visoke pogodnosti izrađenim modelom. Geoprostorni model na prostoru Osječko-baranjske županije i izradba interpolacijske baze podataka omogućili su temelj poljoprivrednicima u donošenju odluka i upravljanju poljoprivrednim gospodarstvima.

\section{ZAHVALA}

Ovaj rad je sufinancirala Hrvatska zaklada za znanost (HrZZ) u sklopu projekta UIP-2017-05-2694.

\section{LITERATURA}

1. Akıncı, H., Özalp, A. Y., \& Turgut, B. (2013). Agricultural land use suitability analysis using GIS and AHP technique. Computers and Electronics in Agriculture, 97, 71-82.

https://doi.org/10.1016/j.compag.2013.07.006

2. Bodirsky, B. L., Rolinski, S., Biewald, A., Weindl, I., Popp, A., \& Lotze-Campen, H. (2015). Global food demand scenarios for the 21 st century. PloS one, 10(11). https://doi.org/10.1371/journal.pone.0139201

3. Bogunović, M., Vidaček, Ž., Racz, Z., Husnjak, S., \& Sraka, M. (1997). Namjenska pedološka karta Republike Hrvatske i njena uporaba. Agronomski glasnik: Glasilo Hrvatskog agronomskog društva, 59(5-6), 363-399.

4. Crnčan, A., Kralik, I., Kristić, J., \& Hadelan, L. (2016). Primjena metoda višekriterijskog odlučivanja u poljopri- vrednoj proizvodnji. Krmiva: Časopis o hranidbi životinja, proizvodnji i tehnologiji krme, 58(1), 33-40.

5. Davis, K. F., Rulli, M. C., Seveso, A., \& D'Odorico, P. (2017). Increased food production and reduced water use through optimized crop distribution. Nature Geoscience, 10(12), 919-924.

https://doi.org/10.1038/s41561-017-0004-5

6. Dedeoğlu, M., \& Dengiz, 0. (2019). Generating of land suitability index for wheat with hybrid system aproach using AHP and GIS. Computers and Electronics in Agriculture, 167, 105062.

https://doi.org/10.1016/j.compag.2019.105062

7. Domazetović, F., Šiljeg, A., Lončar, N., \& Marić, I. (2019). Development of automated multicriteria GIS analysis of gully erosion susceptibility. Applied Geography, 112, 102083.

https://doi.org/10.1016/j.apgeog.2019.102083

8. Eastman, J.R. (1999). Multi-criteria evaluation and GIS. In Goodchild, M.F., Maguire, D.J., Rhind, D., W., (Eds.), Geographical Informational Systems (pp 493-502). John Wiley and Sons: New York, USA.

9. Ennaji, W., Barakat, A., El Baghdadi, M., Oumenskou, H., Aadraoui, M., Karroum, L. A., \& Hilali, A. (2018). GISbased multi-criteria land suitability analysis for sustainable agriculture in the northeast area of Tadla plain (Morocco). Journal of Earth System Science, 127(6), 79. https://doi.org/10.1007/s12040-018-0980-x

10. FAO (Food and Agriculture Organization) (1976). A framework for land evaluation. FAO Soils Bulletin 32. http://www.fao.org/3/x5310e/x5310e00.htm

11. Fick, S. E., \& Hijmans, R. J. (2017). WorldClim 2: new $1-\mathrm{km}$ spatial resolution climate surfaces for global land areas. International Journal of Climatology, 37(12), 4302-4315. https://doi.org/10.1002/joc.5086

12. Hornsey, I. S. (2003). A history of beer and brewing (Vol. 34). Royal Society of Chemistry.

13. Jurišić, M., Plaščak, I., Antonić, O., \& Radočaj, D. (2020). Suitability Calculation for Red Spicy Pepper Cultivation (Capsicum annum L.) Using Hybrid GISBased Multicriteria Analysis. Agronomy, 10(1), 3. https://doi.org/10.3390/agronomy10010003

14. Kazemi, H., \& Akinci, H. (2018). A land use suitability model for rainfed farming by Multi-criteria Decision- 
making Analysis (MCDA) and Geographic Information System (GIS). Ecological engineering, 116, 1-6. https://doi.org/10.1016/j.ecoleng.2018.02.021

15. Magaš, D. (2013). Geografija Hrvatske. Zadar: Meridijani.

16. Martinčić, J., \& Kolak, I. (1993). Ječam-Hordeum vulgare L. Conv. Distichum, sirovina za potrebe industrije slada i piva. Sjemenarstvo, 10(3-4), 163-172.

17. Musakwa, W. (2018). Identifying land suitable for agricultural land reform using GIS-MCDA in South Africa. Environment, Development and Sustainability, 20(5), 2281-2299.

https://doi.org/10.1007/s10668-017-9989-6

18. OSM (OpenStreetMap) Contributors (2019). Planet OSM. https://planet.osm.org/

19. Plaščak, I., Jurišić, M., Radočaj, D., Barač, Ž., \& Glavaš, J. (2019). Hazel plantation planning using GIS and multicriteria decision analysis. Poljoprivreda, 25(2), 79-85. http://dx.doi.org/10.18047/poljo.25.2.11

20. Radočaj, D., Jurišić, M., Gašparović, M., \& Plaščak, I. (2020). Optimal Soybean (Glycine max L.) Land Suitability Using GIS-Based Multicriteria Analysis and Sentinel-2 Multitemporal Images. Remote Sensing, 12, 1463. https://doi.org/10.3390/rs12091463

21. Saaty, T. L. (1990). How to make a decision: the analytic hierarchy process. European journal of operational research, 48(1), 9-26.

https://doi.org/10.1016/0377-2217(90)90057-I
22. Saaty, T. L. (2008). Decision making with the analytic hierarchy process. International journal of services sciences, 1(1), 83-98. https://doi.org/10.1504/IJSSCI.2008.017590

23. Sarkar, A., Ghosh, A., \& Banik, P. (2014). Multi-criteria land evaluation for suitability analysis of wheat: a case study of a watershed in eastern plateau region, India. Geo-spatial Information Science, 17(2), 119-128. https:// doi.org/10.1080/10095020.2013.774106

24. Šiljeg A., Barada M., \& Marić I. (2018). Digitalno modeliranje reljefa, Zagreb: Alfa.

25. Yohannes, H., \& Soromessa, T. (2018). Land suitability assessment for major crops by using GIS-based multi-criteria approach in Andit Tid watershed, Ethiopia. Cogent Food \& Agriculture, 4(1), 1470481. https://doi.org/10.1080/23311932.2018.1470481

26. USGS (US Geological Survey). (2015). Shuttle Radar Topography Mission (SRTM) 1 Arc-Second Global. https://doi.org/10.5066/F7PR7TFT

27. Zhang, J., Su, Y., Wu, J., \& Liang, H. (2015). GIS based land suitability assessment for tobacco production using AHP and fuzzy set in Shandong province of China. Computers and Electronics in Agriculture, 114, 202-211. https://doi.org/10.1016/j.compag.2015.04.004

\section{SUITABILITY MODELING OF AGRICULTURAL LAND FOR BARLEY CULTIVATION USING THE MULTICRITERIA GIS ANALYSIS}

\section{SUMMARY}

The importance of a multicriteria Geographic Information System (GIS) analysis in an agricultural production planning is being expanded because of an increasing necessity for a better and sustainable exploitation of land resources. In this research, a calculation model of agricultural land's suitability for barley cultivation in Osijek-Baranja County was developed, based on a multicriteria GIS analysis. The research procedure was based on the fundamental steps of a multicriteria GIS analysis: setting the analytical goal, determining the criteria, standardizing the values, determining the criterial weights, combining the standardized values and the criteria weights, and validating the results. Five criteria groups were used for a suitability calculation: the geomorphometric, climatic, pedological, hydrological and constraint criteria. The criteria weighting coefficients were determined by the Analytical Hierarchical Process (AHP) method. The suitability values were reclassified in five classed pursuant to the agricultural land's suitability standards stipulated by the Food and Agriculture Organization (FAO). The research results have proven that a moderately suitable (S2) class for barley cultivation is predominantly present in Osijek-Baranja County, occupying $53.00 \%$ of agricultural land. According to the test ARKOD particles, the highest suitability calculation accuracy was achieved for the very suitable (S1) suitability class, with a 99.82-percent accuracy. The developed model represents a basis for suitability calculation of other crops in the Osijek-Baranja County area at the research's meso- and microlevels.

Keywords: suitability model, barley, FAO suitability classes, GIS, Osijek-Baranja County

(Received on January 15, 2020; accepted on May 26, 2020 - Primljeno 15. siječnja 2020.; prihvaćeno 26. svibnja 2020.) 